IZA DP No. 5780

Short-Time Work:

The German Answer to the Great Recession

Karl Brenke

Ulf Rinne

Klaus F. Zimmermann

June 2011 


\title{
Short-Time Work: The German Answer to the Great Recession
}

\author{
Karl Brenke
}

DIW Berlin

Ulf Rinne

IZA

Klaus F. Zimmermann

IZA and University of Bonn

Discussion Paper No. 5780

June 2011

IZA

P.O. Box 7240

53072 Bonn

Germany

Phone: +49-228-3894-0

Fax: +49-228-3894-180

E-mail: iza@iza.org

Any opinions expressed here are those of the author(s) and not those of IZA. Research published in this series may include views on policy, but the institute itself takes no institutional policy positions.

The Institute for the Study of Labor (IZA) in Bonn is a local and virtual international research center and a place of communication between science, politics and business. IZA is an independent nonprofit organization supported by Deutsche Post Foundation. The center is associated with the University of Bonn and offers a stimulating research environment through its international network, workshops and conferences, data service, project support, research visits and doctoral program. IZA engages in (i) original and internationally competitive research in all fields of labor economics, (ii) development of policy concepts, and (iii) dissemination of research results and concepts to the interested public.

IZA Discussion Papers often represent preliminary work and are circulated to encourage discussion. Citation of such a paper should account for its provisional character. A revised version may be available directly from the author. 
IZA Discussion Paper No. 5780

June 2011

\section{ABSTRACT}

\section{Short-Time Work: The German Answer to the Great Recession*}

Short-time work was the "German answer" to the economic crisis. The number of short-time workers strongly increased in the recession and peaked at more than 1.5 million. Without the extensive use of short-time work, unemployment would have risen by approximately twice as much as it actually did. Short-time work has certainly contributed to the mild response of the German labor market to the crisis, but this is likely due to the country-specific context. Although the crisis has been overcome and employment is strongly expanding, modified regulations governing short-time work are still in place. This leads to undesired side effects.

JEL Classification: J65, J68

Keywords: labor market policy, partially unemployed workers, short-time work compensation, economic crisis

Corresponding author:

Ulf Rinne

IZA

P.O. Box 7240

D-53072 Bonn

Germany

E-mail: rinne@iza.org

\footnotetext{
* This paper is a substantially revised, updated and extended version of Brenke et al. (2010). We would like to thank Daniela Geppert for her excellent research assistance and Carolyn Ferguson for her editorial comments. All remaining errors are our own.
} 


\section{Introduction}

Comparatively, Germany has been hit hard by the crisis as shown by the 4.7 percent decline in GDP in 2009. This is about twice the size of the GDP decline in the United States in that same year (OECD, 2010). Nevertheless, the recession has not translated into a strong employment decline in Germany. The slump in output was essentially limited to the export economy. The impact in the labor market was limited, and domestic demand was only depressed by a small degree. Spillover effects to sectors other than the exportoriented ones were limited. According to the Federal Statistical Office, the size of the working population remained at a record level of more than 40 million people through both 2008 and 2009.

Short-time work made a substantial contribution to this astonishing development: the long existing regulations governing its use were already modified at the beginning of the crisis. This significantly helped to cushion the job losses by extending subsidies for a temporary reduction in working hours. In addition, short-time work helped German companies be well prepared for when the demand for their goods increased again. They were able to expand their production without time loss. Short-time work is a rather uncommon instrument internationally, and it therefore may be labeled as the "German answer" to the economic crisis. ${ }^{1}$

Across the world, the immediate policy responses to the economic downturn mostly focused on avoiding job losses as well as stabilizing and stimulating aggregate demand. This was also the aim of the extension of short-time work in Germany. However, other countries put emphasize on extending unemployment benefits (the United States, Japan), enhancing social protection (Brazil, India), avoiding cuts in minimum wages, and on adopting other support measures for low-income groups (Torres, 2010, p. 231). These responses seem to have been largely driven by domestic interests (Stiglitz, 2009) - as this was also the case in regards to short-time work in Germany.

During the course of the crisis, the traditional instrument of short-time work was especially common in Germany's industrial sectors which heavily rely on exports as well as service sectors closely linked to industrial production. In the second quarter of 2009, the peak of the crisis in Germany, one in

\footnotetext{
${ }^{1}$ Similar regulations exist only in some other European countries, e.g., in France (Eichhorst and Marx, 2009). However, somewhat related, it is known that temporary work may reduce unemployment duration (see, e.g., de Graaf-Zijl et al., 2011).
} 
three employees with jobs that were subject to social security contributions in metal production experienced a reduction in working hours. Similarly, in the automobile industry, the ratio was one in four. However, short-time workers could also be found in industry sectors that have been unaffected by the drop in demand from the recession.

Meanwhile, in the second quarter of 2011, production has reached the before-crisis level. Unemployment is steadily decreasing and the number of employees is about half a million higher than at the pre-crisis peak in autumn 2006. In fact, employment has reached an all-time high in the history of the Federal Republic of Germany. Although the post-crisis recovery could already be foreseen in 2010, favorable modifications in the conditions for the use of short-time work were prolonged in autumn 2010. Therefore, it is possible to obtain the related benefits up until the end of 2012. As a result, and despite of massive increases in production, the number of short-time workers is still considerably higher than before the crisis.

This paper presents an analysis of how short-time work has developed and where in the economy it has been especially widespread, particularly during the great recession. ${ }^{2}$ Potential problems accompanying short-time work are highlighted, despite its benefits during the crisis. This instrument has certainly helped to cushion the impact of the crisis on the German labor market. Nevertheless, there are clear indications that its effectiveness has been due to the particular circumstances and the way the crisis has hit Germany. Therefore, it is unlikely that the labor markets of other countries would have similarly benefited from the extensive use of short-time work during the latest recession.

\section{Short-Time Work: A Look Back in History}

The origins of a specified payment made to employees in the case of shorttime work date back to the beginning of the last century. The precursor was an amendment on tobacco tax in 1909, where a rise in tolls and taxes meant less work in the tobacco processing plants (Holzmayer, 1989). After World War I, short-time work was integrated into the newly created unemployment benefit scheme in all sectors of the industry. The first regulations came into

\footnotetext{
${ }^{2}$ Although, in principle, there are three types of short-time work in Germany, our analysis mainly concentrates on short-time work resulting from recession or general economic conditions in an attempt to overcome a temporary crisis. Other forms of short-time work are disregarded (see Brenke et al., 2010, for further details).
} 
effect in November 1918. ${ }^{3}$ Short-time work was deployed on a massive scale during the first economic crisis of the Weimar Republic. In 1924, a quarter of all blue and white-collar workers were involved in short-time work; and unemployment was at 11 percent. Although short-time work decreased considerably in the following years, known as the "Golden Twenties," it remained high compared to today. By the time the world economic crisis peaked in 1932, the share of short-time workers had increased to more than 20 percent. However, this could hardly ease the burden of the labor market in light of the dramatic underemployment - unemployment had reached 44 percent. $^{4}$

Regulations governing short-time work during the Weimar Republic were broadly adopted by the Federal Republic. Short-time work was again deployed on a large scale in the second half of the 1960s, which witnessed the first post-war economic crisis. The number of short-time workers had climbed to 188,000 by the end of the second quarter of 1967 (Sachverständigenrat, 1969, p. 17). This increase, together with 500,000 unemployed individuals, was perceived very ominously after the long period of prosperity. However, after a little over a year, short-time work had once again disappeared and unemployment had greatly reduced. A vigorous rise in short-time work in the middle of the 1970s and the first half of the 1980s resulted from the oil and energy crisis's: in 1975 short-time workers numbered 773,000; and in 1983 they numbered 675,000 (Statistisches Bundesamt et al., 2008, p. 120).

German reunification presented a special case. Following the monetary, economic and social union, production in the former German Democratic Republic collapsed at lightning speed and underemployment increased drastically. Initially, the response was predominantly focused on the deployment of short-time work. In the beginning of 1991 more than a quarter of all employees in East Germany were employed in short-time work. The reduction in working hours was often diminished to as much as 100 percent. On the one hand, the desire was to retain the workforce because they represented the intrinsic essence of the firms, with a forwarding view towards privatization. On the other hand, the soaring rise in unemployment was supposed to be

\footnotetext{
3 "Employees (...) who in their workplace (...) fail to meet the normal amount of hours are to be compensated for the missing hours." (§9(2)1 of the Regulation of Welfare for Unemployment of November 13, 1918).

4 Data from "Wirtschaft und Statistik," Statistisches Reichsamt (cited in Kuczynski, 1966, p. 197f.).
} 
monitored. This backdrop meant that short-time work was widely utilized, since time was needed to create and introduce other labor market policy instruments to create jobs, and then encourage further education and retraining. As these measures became available, the number of short-time workers in East Germany drastically declined (Figure 1). Hence, short-time work during this period did not serve as an instrument to bridge a temporary production gap but instead as a first response to help cushioning the social shock of the economic upheaval.

A short time later, following the end of the reunification boom, the number of short-time workers once again increased - this time primarily in West Germany. In the two periods of economic downturn which were to follow (1996/1997 and 2001/2004), short-time work, in contrast, increased relatively little; although unemployment rose steeply. There may well be several reasons why temporary capacity underutilization caused so little usage of short-time work during the last recessions. ${ }^{5}$ One factor could be that legislators made the use of the instruments successively less attractive from 1988 to 1994 . Whilst employers had been completely reimbursed for social security contributions up to 1988, after 1994 it was primarily the employer who had to bear the costs (Bach and Spitznagel, 2009, p. 4).

Even so, in the recent economic crisis short-time work was applied more extensively than ever before in the history of the German Federal Republic, following the upheaval of reunification. Amendments to laws and regulations certainly made a substantial contribution.

\section{Changes to Short-Time Regulations Following the Crisis}

During the course of the financial and economic crisis, the rules governing the length of time the wage supplement was paid were repeatedly changed. The law specified a maximum period of six months, which could be temporarily extended if the labor market was tight. In November 2008 the period was increased from 12 to 18 months. In May 2009 this period was extended to 24 months; however, this applied to short-time work which had started in 2009. There was also an additional change to the regulations in December 2009: those who have had their hours reduced since January 2010 received the short-time work allowance of a maximum period of 18 months. In December

${ }^{5}$ Eichhorst and Marx (2009, p. 7) attribute the relatively low adoption of short-time work from the middle of the 1990s to the onset of the last recession to the loss of importance due to more flexible working times resulting from wage bargaining and company-specific agreements. 
2010, this maximum period was set at 12 months for those persons who started short-time work in 2011. Therefore, short-time work continues to be subsidized under favorable conditions until the end of 2012.

The new regulations also abandoned the "one-third rule," which stipulated that short-time work can only be implemented when at least a third of employees incur a 10 percent loss of earnings. Since 2009 it has been sufficient to have a single worker facing a reduction in working hours.

Following this amendment in the regulation from January 2009, employers are required to pay only 50 percent of the social security contributions in the first six months of short-time work; the other half is reimbursed. After this initial period the Federal Employment Agency completely reimburses payments. If the worker is involved in further training, there are no costs in the first six months of the short-time work. It is still not known to extent at which this rule has motivated individuals (or firms) to engage in vocational training. Studies have shown that in the past, only few firms combined shorttime work with further training. However, evidence exists showing that this may have changed. ${ }^{6}$

Calculations show that if employers are required only to pay 50 percent of the social security contributions, the residual costs in the manufacturing sector still account for 35 percent of the usual labor costs; if 100 percent is assumed, this figure then becomes 24 percent (Bach and Spitznagel, 2009). These costs are the employer's burden to engage in short-time work.

An additional modification extended short-time work to also include temporary workers, who have been allowed to participate since the beginning of 2009. It is no longer required that workers have to "clock-in" a negative balance of hours worked before short-time work can commence. Finally, employers do not have to re-register short-time work if there is an interruption of more than two months within the period claimed.

\section{The Development of Short-Time Work in the Economic Crisis}

These modifications have made the use of short-time work very attractive. In the recent economic crisis, many more firms have resorted to short-time work than in the past (Figure 2). However, the average number of short-time workers per firm is comparatively low. Hence, there are many firms with rela-

${ }^{6}$ In 2003 only 5 per cent of companies with short-time work were engaged in further education. It must be said, however, that there were no incentives at that time, such as the reimbursement of social security benefits, as is the case today (Crimmann and Wießner, 2009). 
tively few short-time workers - which is in contrast to the first half of the 1990s in particular. The number of short-time workers drastically increased from October 2008 and then peaked in the second quarter of 2009 (Figure 3). In May 2009, more than 1.5 million employees received the short-time work allowance due to economic reasons. In February 2011, the month in which the most recent data is available, there was a substantial decline in this figure to 150,000 .

Without the extensive use of short-time work, unemployment in Germany would have undoubtedly risen much more steeply - in absolute terms around twice as much as it had actually grown since the middle of 2009. In addition to the decrease in the number of short-time workers, the development of employment and unemployment indicates more of a loosening rather than a tightening of the labor market (Figure 4). Nevertheless, the number of short-time workers is still considerably higher than before the crisis, when there were about 30,000 short-time workers registered. In the course of expanding production and employment, the registration of shorttime work decreased (Figure 5). ${ }^{7}$ Yet, their number is still considerably higher than in the first half of 2008. Another surprising fact is the seasonal pattern which short-time works exhibits already since the end of 2009. This should not occur as there is specific type of short-time work explicitly targeted at seasonal employment losses, which is not included in our data.

As was the case in the past, over the course of the reduction in shorttime work the number of employees affected by this fell significantly greater than the number of firms engaging in short-time work. Accordingly, the average number of short-time workers per firm also fell (Figure 6), at least until autumn 2010. This result is a consequence of a smaller reduction in shorttime work in smaller firms compared to a larger reduction in larger firms (Table 1). The use of short-time work has moved to smaller companies.

At the peak of the crisis, one in five companies with 500 and more employees were affected by short-time work. More than one third of all shorttime work could be attributed to these companies. At the beginning of 2011, however, there was hardly any short-time work in large companies; only one in eight short-time workers could be contributed to the company of this size. Among the smallest companies (less than 20 employees), there was already a small share with short-time work during the crisis - a share which has been decreasing even more recently. Here as well, the number of short-time work-

\footnotetext{
${ }^{7}$ It is not clear whether the registration of short-time work actually results in such a working circumstance within the registered period.
} 
ers has reduced, although not as rapidly as among the largest companies. Of all short-time workers, one in three could be attributed to small companies at the beginning of 2011, while it was only one in ten in the second quarter of 2009.

\section{Expansion of Short-Time Work: Particularly Manufacturing}

With regards to different sectors, there are large differences in the extent of the use of short-time work. Before the economic crisis, short-time work could also be found in the construction industry to a considerable degree. The main emphasis shifted to the manufacturing sector during the course of the crisis. In the middle of 2009 this sector accounted for four fifths of short-time workers. However, not only did firms in manufacturing determine the rise of short-time work, they also governed its fall. The development of short-time work in other sectors generally proceeded less dynamically. The data on the number of workers registered as short-time also illustrate the dwindling importance of firms in manufacturing. Recently, they accounted for only a half of all those registered. Nevertheless, the effect of short-time work on this sector has been far greater as only one in four employees subject to social security contributions work in manufacturing.

The main reason for the extensive use of short-time work in this sector was because the crisis hit Germany mainly through a drastic decrease in foreign demand; and the country's export industry is driven in particular by firms in manufacturing. The use of short-time work could mitigate, but not avoid, work place reduction in this sector. Of the economically important sectors, manufacturing is the only one in which the number of employees is still smaller than before the crisis. Short-time work could alleviate lay-offs primarily in the beginning of the crisis. However, lay-offs increased rapidly until April 2009 - it peaked at a full-time equivalent of almost 300,000 workers (Figure 7). At the same time, one in six employees subject to social security contributions was receiving short-time work allowances due to a reduction of working hours in light of the economic situation. After that, the number of short-time workers continuously decreased - but employment decreased at a similar rate. Whereas in the beginning of the crisis the number of short-time workers exceeded the number of lay-offs, employment continued to decrease even when the reduction in short-time work had already begun. This was the case until the end of 2009. At that time, short-time work was still extensively deployed with a full-time equivalent of 170,000 workers. Since the beginning of 2010 , employment in manufacturing has steadily in- 
creased (apart from seasonal influences), and short-time work has further reduced.

This indicates that despite the extensive use of short-time work, certain manufacturing firms were not able to completely stabilize employment. Production losses were too severe in a few instances, which even induced some, but not many companies to close. On the other hand, the majority of manufacturing firms benefited from short-time work as lay-offs could be avoided and employment levels maintained. Another benefit was when demand picked up in the second quarter of 2009, these firms were immediately ready and well prepared to increase working hours and restore production levels. Such a rapid adjustment to the improved situation was only possible because the necessary personnel was available without delay, subsequently a costly and time consuming hiring and training of new personnel could be avoided.

A survey of branches in the manufacturing sector reveals a more diverse picture: short-time work was particularly widespread in the production of basic metals, the automobile industry, engineering, the production of electrical equipments, and in the rubber and plastic industry - all of which are export-oriented branches (Table 2). The same goes for textile manufacturing and the production of computers, electronic and optical products. In comparison, short-time work was used less extensively in sectors which cater more to the domestic market. Thus, the share of short-time work in the food industry was a mere 0.5 percent in the middle of 2009. Furthermore, not every export-oriented industry had to extensively adopt short-time work. One example is the pharmaceutical industry, whose turnover is generally less dependent on fluctuations in the world economy: this sector's rate of shorttime work was 0.8 percent.

A relatively large number of short-time workers are to be found in areas of the service sector in which a considerable share of the activity is industrial - such as the transport sector, warehousing, wholesale trade, engineering services and temporary employment agencies. Similar arguments hold for IT services and consulting. However, there are sectors in the service industry in which there are no discernible reasons for the reduction in work hours. These sectors should not have been affected, either directly or indirectly, by weak foreign demand. For example, travel agencies are geared towards domestic consumption; and domestic demand in Germany had remained stabile despite the economic crisis. In the construction sector the extent of short-time work that was supposedly put down by the economic conditions was surprisingly high; despite a significant increase in production within this sector dur- 
ing the middle of 2009 as well as the availability of the seasonal short-time allowance for a loss of working hours due to weather conditions. Other sectors of the economy, such as public administration, education and teaching, as well as health care and social services, are by and large not sensitive to economic circumstances - nevertheless, short-time workers can also be found here. In the second quarter of 2009, more than 2,000 short-time workers were registered in public administration and more than 3,000 in the hotel and restaurant industry. It may be that these sectors have resorted to shorttime work not because of economic circumstances but more because of internal difficulties or structural problems.

Short-time workers are concentrated in particular regions of Germany (Schwengler and Loibl, 2010). Firms in Southern and Western Germany particularly utilized short-time work. Not surprisingly, firms in the manufacturing sector are overrepresented in those regions such as Bavaria, BadenWürttemberg and North Rhine-Westphalia. A more detailed analysis reveals that rather than firm-specific characteristics, the regions themselves are related to the regional distribution of short-time work in 2009 (Crimmann et al., 2010). Regions with a relatively high number of short-time workers are those regions in which the industry is predominantly export-oriented.

\section{Proportion of Long-Term Short-Time Workers Grows}

The average loss of hours for each short-time worker has changed little since the middle of 2009; in the past this average had risen significantly during the expansion phase of short-time work (Figure 8). The data for the middle of 2009 and for autumn 2010 show the same picture. Half of the short-time workers had working hours reduced by up to a quarter of their contractual obligation, and about one in ten had their normal working hours reduced by more than a half. The average loss of hours amounted to nearly 30 percent. Meanwhile, less than 1 percent of all employees subject to social security contributions were involved in short-time work.

Even as the total number of short-time workers fell, the share of employees who had experienced a loss of hours over a prolonged period of time rose considerably (Figure 9). In autumn 2010 about 60 percent of short-time workers had been working for more than one year, one of three for more than 18 months. This indicates a structural hardening and the establishment of a base of long-term short-time workers. This form of long-term unemployment is predominantly found in manufacturing, especially in the metal sector such as engineering, the automobile industry and in the production of 
electrical and electronic products. Nonetheless, there are also non-negligible numbers of long-time short-time workers in the IT industry, in engineering offices, in parts of the construction sector, and even in retail. The latter industries have hardly been hit by the crisis. In fact, employment has been steadily rising in these industries.

\section{Employee Benefits and Employer Costs of Short-Time Work}

The loss of income an employee incurs through short-time work is kept to a minimum. The hours worked are paid as usual. The fall in income due to lost working hours is partly compensated by the Federal Employment Agency. This amounts to 60 percent of the net earnings difference for workers without children and 67 percent for those with children. In some collective wagebargaining sectors, the supplement is partly paid by the employer. ${ }^{8}$ Social security contributions continue as before, and paid leave (public holidays, vacation, as well as any other contractual agreements) also remain unaffected by the rules governing short-time work. Generally speaking, this also applies to other agreed payments (Christmas and vacation bonuses, company pensions and other investment contributions etc.). The application of the principle of solidarity thus avoids individual loss of income through relatively small, general reductions.

It proves to be to the employers' benefit that in times of weak economic conditions, the policy instrument of short-time work preserves employees in the established core of the company and removes the necessity of having to employ new personnel once demand improves. In this manner, they are spared the costs of finding and training new personnel, which can be quite considerable. ${ }^{9}$ Furthermore, employers avoid severance payments and potential claims against unfair dismissal.

Along with the advantages of short-time work, however, companies are also faced with particular disadvantages. Labor costs incurred with short-time work do not proportionately fall with the reduction in hours worked because

\footnotetext{
${ }^{8}$ This applies to the chemical industry, the metal industry in the region Nordwürttemberg-Nordbaden, Deutsche Bahn, Deutsche Telekom, wood and plastic processing industries in Saxony. In the textile industry in Westfalen/Osnabrück and in the apparel industry in Bavaria, the weekly working hours can only be reduced to a specific number of hours. Any further reductions are fully paid. See Bispinck (2009) for further details.

${ }^{9}$ For example, it is common for temporary employment agencies to demand a commission fee of three months gross salary when the company hires the skilled worker.
} 
of the residual costs due to a lagged adjustment of variable costs (e.g., costs remain for paid leave and other agreed payments). In addition, social security contributions still must be paid. Up to 2009, the employer was responsible for both the employer's and the employee's share of social security contributions. Models for the manufacturing sector indicate that under these regulations, the residual costs for each working hour lost accounted for 46 percent of the labor costs. In sectors which have an additional net wage protection, such as the chemical industry, can even be as high as 59 percent (Bach and Spitznagel, 2009, p. 6). But recent changes have made the use of short-time work more attractive as well as reduced residual costs on the employer's side.

\section{Extension of Amendments to Laws and Regulations}

Short-time work may be an adequate instrument for the temporary stabilization of the labor market. However, negative effects can also appear as they have already in the medium term. Firms could be tempted by the possibility of longer implementation of short-time work in order to neglect the necessary efforts for improvement: in particular, improvements in competitiveness and on putting focus on new market conditions which require adjustments to the structure and scope of the personnel. Therefore, policymakers should be contemplating an early exit out of the amendments to laws and regulations governing short-time work, which were changed in light of the economic crisis.

In the beginning of 2010 the discussion has mainly concentrated on conflicting suggestions instead of considering possible scenarios for a phasing out of short-time work. Suggestions have been made to once again extend the period of time for the short-time work allowance and a continuation of the reimbursement of social security contributions. The Social Democratic Party (SPD) had suggested increasing the allowance period to a maximum of 36 months (SPD, 2010). The idea is to grant long-term short-time workers a longer period of wage compensation to protect them from entering unemployment. Additionally, the Federal Employment Agency would reimburse social security contributions until the end of 2011.

Similarly, an initiative from unions and management in the metal industry has had the aim of prolonging the use of short-time work. The wage agreement reached in February 2010 introduced a union bargaining clause once the official short-time regulations were supposed to expire. The costs of 
which will be borne by both the employers and employees. ${ }^{10}$ In accordance to this agreement, however, the Federal Employment Agency will bare a share of the costs by reimbursing the social security contributions for the working hours lost, as already is the case.

The final outcome of this process has been that the rules governing short-time work during the crisis have been essentially extended until March 2012 (see Bundesregierung, 2010). In particular, employers will continue to be required to pay only 50 percent of the social security contributions in the first six months of short-time work; the other half will be reimbursed by the Federal Employment Agency until March 31, 2012.

\section{Incentives for Further Education and Training}

Modification of the regulations governing short-time work has also created incentives for investments in further education and training. To what extent the benefits were taken advantage of is difficult to judge.

However, further education has lost its importance since the beginning of the crisis: the number of employees who received the short-time allowance in the initial six months has fallen over the course of time - and the incentives to invest in further education and training are relevant only for these short-time workers. Moreover, in 2009, firms requested only 17 percent of the budget which was provided by the Federal Employment Agency for further education and training of short-time workers (Crimmann et al., 2010). Further information on the usage of the benefits for further education and training are not available. In sum, it seems plausible to assume that this special regulation was hardly being utilized.

\section{Conclusions and Outlook}

Short-time work is an instrument which can be utilized by firms to react flexibly to changing economic circumstances. In periods in which the economy is struggling, the social blow of lost working hours can be cushioned; moreover when the situation improves, the necessary personnel are available immediately. Therefore, it was correct to make the regulations governing short-time work more attractive to those affected by the crisis. Due to this, a rise in un-

\footnotetext{
${ }^{10}$ The employees will continue to forgo a part of their income; the employers will supplement the wages to the amount of the short-time work allowance and to cover the residual costs.
} 
employment was hindered. The vigorous adoption of the short-time work regulations during the crisis is proof of the success of this policy.

But one should not draw the conclusion that this instrument can help to cushion the labor market impact of recessions in any context. The success of such a policy depends on the specific circumstances and the particular nature of the crisis. In the German situation, its success is due to the fact that the recent crisis has mainly affected export-oriented sectors, particularly the manufacturing industry. Alongside these conditions, the extensive use of short-term work has certainly contributed to the surprisingly mild response of the German labor market to the crisis - at least temporarily.

There is the danger with all forms of state intervention associated with cash benefits or other instruments (such as transfer payments, tax breaks or subsidies) which are open to abuse or lead to deadweight losses. This also seems to be the case with short-time work in Germany. Short-time workers are also found in companies in the industry sectors that were not expected to be confronted with a loss of working hours due to the economic conditions. A narrower interpretation and a consistent application of the laws, together with tighter controls, could have overcome some shortcomings.

However, policymakers in Germany have taken the wrong approach. In the end of 2010, when the number of employees had already been increasing for a considerable period, the regulations governing short-time work were extended another time. Politicians were apparently willing to obey to certain pressure groups.

Keeping in mind the broader picture of diverse policy responses to the great recession, Germany's action to extend subsidies for short-time work fits almost perfectly into the picture sketched by Stiglitz (2009), who argues that "most actions only fix the plumping." The more fundamental problems, however, still need to be addressed. Torres (2010) takes the same stance when he points out that the "causes of the disease" have yet to be addressed. Short-time work, like many other policy measures around the world, has only provided temporary respite. Although it seems to be the case that this temporary respite was sufficient to cushion the crisis' impact on the German labor market, one should be very cautious when generalizing from this result. 


\section{References}

Bach, H.-U. and E. Spitznagel (2009): "Betriebe zahlen mit - und haben was davon," IAB Kurzbericht 17/2009, Institute for Employment Research (IAB), Nuremberg.

Bispinck, R. (2009): "Tarifliche Regelungen zur Kurzarbeit - Übersicht über 18 Wirtschaftszweige," Elemente qualitativer Tarifpolitik 66, Düsseldorf.

Brenke, K., U. Rinne and K. F. Zimmermann (2010): "Kurzarbeit: Nützlich in der Krise, aber nun den Ausstieg einleiten," Wochenbericht des DIW Berlin 77(16), p. 2-13, German Institute for Economic Research (DIW Berlin), Berlin.

Bundesregierung (2010): "Entwurf eines Gesetzes für bessere Beschäftigungschancen am Arbeitsmarkt - Beschäftigungschancengesetz," Drucksache des Deutschen Bundestages 17/1945, Berlin.

Crimmann, A. and F. Wießner (2009): "Verschnaufpause dank Kurzarbeit," IAB Kurzbericht 14/2009, Institute for Employment Research (IAB), Nuremberg.

Crimmann, A., F. Wießner and L. Bellmann (2010): "The German Work-sharing System: An Instrument for the Crisis," Conditions of Work and Employment Series 25, International Labour Office (ILO), Geneva.

de Graaf-Zijl, M., G. J. van den Berg and A. Heyma (2011): "Stepping Stones for the Unemployed: The Effect of Temporary Jobs on the Duration until (Regular) Work," Journal of Population Economics, 24(1), p. 107-139.

Eichhorst, W. and P. Marx (2009): "Kurzarbeit: Sinnvoller Konjunkturpuffer oder verlängertes Arbeitslosengeld?," IZA Standpunkte 5, Institute for the Study of Labor (IZA), Bonn.

Fichtner, F., K. Bernoth, F. Bremus, K. Brenke, C. Dreger, B. Erdogan, H. Hagedorn, V. Kuzin, K. Moll, M. Podstawski, J. Scheppe und K. F. Zimmermann (2010): "Sommergrundlinien 2010," Wochenbericht des DIW Berlin 77(26), p. 2-28, German Institute for Economic Research (DIW Berlin), Berlin.

Holzmayer, W. T. (1989): Kurzarbeitergeld und Schlechtwettergeld: Ein entwicklungsgeschichtlicher Vergleich, Rheinfelden-Freiburg-Berlin.

Kuczynski, J. (1966): Die Geschichte der Lage der Arbeiterklasse, Band 5, Berlin.

Kümmerling, A., M. Schietinger, D. Voss-Dahm and G. Worthmann (2008): "Bericht zu den Wirkungen des Saison-Kurzarbeitergeldes und der damit einhergehenden ergänzenden Leistungen," Endbericht, Drucksache des Deutschen Bundestages 16/11487, Berlin.

OECD (2010): OECD Economic Outlook 86, Volume 2/2009, Organization for Economic Cooperation and Development (OECD), Paris.

Sachverständigenrat (1969): "Alternativen außenwirtschaftlicher Anpassung," Jahresgutachten 1968/69, Sachverständigenrat zur Begutachtung der gesamtwirtschaftlichen Entwicklung, Stuttgart und Mainz.

Schneider, H., K. Brenke, B. Jesske, L. Kaiser, U. Rinne, M. Schneider, J. Steinwede and A. Uhlendorff (2007): "Evaluation der Maßnahmen zur Umsetzung der Vorschläge der Hartz-Kommission - Bericht 2006," IZA Research Report 10, Institute for the Study of Labor (IZA), Bonn. 
Schwengler, B. and V. Loibl (2010): "Aufschwung und Krise wirken regional unterschiedlich," IAB Kurzbericht 1/2010, Institute for Employment Research (IAB), Nuremberg.

SPD (2010): "Beschäftigte vor Arbeitslosigkeit schützen - Konditionen für Kurzarbeit verbessern," Drucksache des Deutschen Bundestages 17/523, Berlin.

Statistisches Bundesamt, Gesellschaft Sozialwissenschaftlicher Infrastruktureinrichtungen, Wissenschaftszentrum Berlin für Sozialforschung (2008): Datenreport 2008: Ein Sozialbericht für die Bundesrepublik Deutschland, Bonn.

Stiglitz, J. (2009): "The Global Crisis, Social Protection and Jobs," International Labour Review, 148(1-2), p. 1-13.

Torres, R. (2010): "Incomplete Crisis Responses: Socio-Economic Costs and Policy Implications," International Labour Review, 149(2), p. 227-237. 
Table 1

Firms engaged in short-time work by firm size

\begin{tabular}{|c|c|c|c|c|c|c|c|c|}
\hline \multirow{2}{*}{ seg } & \multicolumn{7}{|c|}{ Firms with ... employees } & \multirow[b]{2}{*}{ Total } \\
\hline & $1-9$ & $10-19$ & $20-49$ & $50-99$ & $100-199$ & $200-499$ & 500 and above & \\
\hline \multicolumn{9}{|c|}{ Firms with short-time work - percentage of all firms ${ }^{1}$} \\
\hline । 2009 & 0,6 & 1,9 & 3,0 & 4,6 & 6,5 & 8,5 & 11,1 & 1,2 \\
\hline || 2009 & 1,5 & 4,5 & 7,1 & 10,4 & 13,8 & 16,8 & 18,9 & 2,7 \\
\hline III 2009 & 1,7 & 4,7 & 7,3 & 10,3 & 12,9 & 15,8 & 17,9 & 2,9 \\
\hline IV 2009 & 1,7 & 4,4 & 6,9 & 9,3 & 11,7 & 14,2 & 16,8 & 2,8 \\
\hline I 2010 & 1,6 & 3,4 & 4,9 & 6,4 & 7,7 & 8,7 & 10,2 & 2,3 \\
\hline II 2010 & 1,6 & 3,4 & 4,9 & 6,4 & 7,7 & 8,7 & 10,2 & 2,3 \\
\hline III 2010 & 1,2 & 2,2 & 3,1 & 3,9 & 4,6 & 4,8 & 5,2 & 1,6 \\
\hline IV 2010 & 1,0 & 1,7 & 2,3 & 2,8 & 3,5 & 3,7 & 4,2 & 1,3 \\
\hline Jan - Feb 2011 & 0,6 & 1,0 & 1,3 & 1,5 & 1,8 & 1,9 & 1,9 & 0,8 \\
\hline \multicolumn{9}{|c|}{ Share of firms with short time-workers (percentage) } \\
\hline 12009 & 43,2 & 14,7 & 15,6 & 8,7 & 6,2 & 4,3 & 2,2 & 100 \\
\hline II 2009 & 44,2 & 15,7 & 16,1 & 8,8 & 5,9 & 3,8 & 1,7 & 100 \\
\hline III 2009 & 47,4 & 15,3 & 15,5 & 8,1 & 5,1 & 3,3 & 1,5 & 100 \\
\hline IV 2009 & 49,7 & 15,0 & 15,1 & 7,6 & 4,9 & 3,1 & 1,4 & 100 \\
\hline | 2010 & 53,1 & 14,8 & 14,2 & 6,8 & 4,1 & 2,5 & 1,2 & 100 \\
\hline || 2010 & 56,5 & 13,9 & 13,2 & 6,4 & 3,9 & 2,3 & 1,0 & 100 \\
\hline III 2010 & 61,7 & 12,8 & 11,5 & 5,5 & 3,3 & 1,8 & 0,8 & 100 \\
\hline IV 2010 & 63,8 & 12,3 & 10,9 & 5,0 & 3,1 & 1,7 & 0,7 & 100 \\
\hline Jan - Feb 2011 & 64,7 & 12,8 & 10,8 & 4,5 & 2,7 & 1,5 & 0,6 & 100 \\
\hline \multicolumn{9}{|c|}{ Short-time workers - percentage of all employees ${ }^{1}$} \\
\hline I 2009 & 0,6 & 1,0 & 1,5 & 2,2 & 3,0 & 4,0 & 6,0 & 3,1 \\
\hline || 2009 & 1,3 & 2,3 & 3,3 & 4,3 & 5,4 & 6,8 & 8,8 & 5,2 \\
\hline III 2009 & 1,5 & 2,3 & 3,1 & 3,7 & 4,3 & 5,1 & 5,9 & 4,0 \\
\hline IV 2009 & 1,4 & 2,1 & 2,7 & 3,2 & 3,6 & 4,3 & 5,0 & 3,4 \\
\hline | 2010 & 1,3 & 1,4 & 1,6 & 1,8 & 1,8 & 1,8 & 2,0 & 1,8 \\
\hline II 2010 & 1,3 & 1,4 & 1,6 & 1,8 & 1,8 & 1,8 & 2,0 & 1,8 \\
\hline III 2010 & 0,9 & 0,9 & 0,9 & 0,9 & 0,9 & 0,7 & 0,7 & 0,9 \\
\hline IV 2010 & 0,8 & 0,7 & 0,7 & 0,7 & 0,7 & 0,6 & 0,6 & 0,4 \\
\hline Jan - Feb 2011 & 0,7 & 0,6 & 0,6 & 0,6 & 0,5 & 0,5 & 0,3 & 0,6 \\
\hline \multicolumn{9}{|c|}{ Share of short time-workers (percentage) } \\
\hline I 2009 & 3,7 & 3,4 & 7,6 & 8,9 & 12,5 & 19,4 & 44,5 & 100 \\
\hline II 2009 & 4,8 & 4,5 & 9,5 & 10,4 & 13,3 & 19,4 & 38,1 & 100 \\
\hline III 2009 & 6,8 & 5,7 & 11,3 & 11,6 & 13,5 & 18,5 & 32,7 & 100 \\
\hline IV 2009 & 7,6 & 6,0 & 11,6 & 11,4 & 13,1 & 17,9 & 32,3 & 100 \\
\hline I 2010 & 9,6 & 6,9 & 12,4 & 11,6 & 12,6 & 16,4 & 30,5 & 100 \\
\hline |I 2010 & 13,1 & 8,1 & 13,7 & 12,5 & 12,9 & 15,1 & 24,6 & 100 \\
\hline III 2010 & 19,4 & 9,9 & 15,2 & 13,1 & 12,5 & 12,0 & 17,8 & 100 \\
\hline IV 2010 & 20,4 & 9,6 & 14,4 & 12,4 & 12,3 & 12,3 & 18,6 & 100 \\
\hline Jan - Feb 2011 & 22,0 & 11,1 & 16,3 & 13,3 & 12,0 & 13,7 & 11,6 & 100 \\
\hline
\end{tabular}


Table 2

Sectors with extensive use of short-term work (2nd Quarter 2009)

\begin{tabular}{|c|c|c|c|c|c|}
\hline & $\begin{array}{l}\text { Number of short- } \\
\text { time workers }\end{array}$ & $\begin{array}{c}\text { Short-time } \\
\text { workers, full time- } \\
\text { equivalents }\end{array}$ & $\left|\begin{array}{c}\text { Reduced working } \\
\text { time per short-time } \\
\text { worker (p.c.) }\end{array}\right|$ & $\begin{array}{l}\text { Share of short- } \\
\text { time workers }{ }^{1}\end{array}$ & $\begin{array}{l}\text { Share of reduced } \\
\text { workung time }^{1}\end{array}$ \\
\hline \multicolumn{6}{|l|}{ Sectors with above-average share of short-time workers } \\
\hline Manufacture of basic metals & 120887 & 29032 & 24,0 & 37,4 & 9,0 \\
\hline Manufacture of motor vehicles, trailers & 223509 & 58371 & 26,1 & 28,4 & 7,4 \\
\hline Manufacture of electrical equipment & 81377 & 19369 & 23,8 & 24,1 & 5,7 \\
\hline Manufacture of fabricated metal products & 181421 & 49758 & 27,4 & 24,0 & 6,6 \\
\hline Manufacture of rubber and plastic products & 78934 & 17478 & 22,1 & 22,8 & 5,1 \\
\hline Manufacture of machinery and equipment & 222391 & 64409 & 29,0 & 22,8 & 6,6 \\
\hline Manufacture of textiles & 16816 & 3965 & 23,6 & 21,8 & 5,1 \\
\hline Manufacture of computer, electronic and optical products & 72917 & 18007 & 24,7 & 17,0 & 4,2 \\
\hline Manufacture of leather and related products & 2003 & 457 & 22,8 & 12,7 & 2,9 \\
\hline Manufacture of basic chemicals & 40567 & 8794 & 21,7 & 12,6 & 2,7 \\
\hline Manufacture of non-metallic mineral products & 24353 & 6271 & 25,7 & 12,0 & 3,1 \\
\hline Manufacture of pulp, paper and paperboard & 13077 & 2587 & 19,8 & 10,3 & 2,0 \\
\hline Manufacture of furniture & 11757 & 2539 & 21,6 & 10,1 & 2,2 \\
\hline Repair of fabricated metal products, machinery and equipment & 12972 & 3388 & 26,1 & 9,7 & 2,5 \\
\hline Manufacture of wood and of products of wood & 10354 & 2685 & 25,9 & 9,2 & 2,4 \\
\hline Travel agencies, tour operator & 5360 & 739 & 13,8 & 7,5 & 1,0 \\
\hline Other manufacturing & 13516 & 3280 & 24,3 & 6,3 & 1,5 \\
\hline Quarrying of stone, sand and clay & 2440 & 838 & 34,4 & 6,2 & 2,1 \\
\hline Printing and reproduction of recorded media & 10170 & 2386 & 23,5 & 5,9 & 1,4 \\
\hline Warehousing and support activities for transportation & 31680 & 7016 & 22,1 & 4,9 & 1,1 \\
\hline \multicolumn{6}{|l|}{$\begin{array}{l}\text { Other sectors with a substantial number of short-time } \\
\text { workers }\end{array}$} \\
\hline Architectural and engineering activities; technical analysis & 17594 & 6459 & 36,7 & 4,4 & 1,6 \\
\hline Wholesale trade & 54843 & 13060 & 23,8 & 4,1 & 1,0 \\
\hline Activities of employment placement agencies & 20638 & 8197 & 39,7 & 3,7 & 1,5 \\
\hline Management consultancy activities & 10329 & 2562 & 24,8 & 2,7 & 0,7 \\
\hline Specialised construction activities & 25891 & 9096 & 35,1 & 2,4 & 0,8 \\
\hline
\end{tabular}

1 Share of short-time workers resp. full time-equivalents among employees subject to social security contributions.

Sources: Federal Employment Agency, own calculations. 
Figure 1

Number of short-time workers in Germany

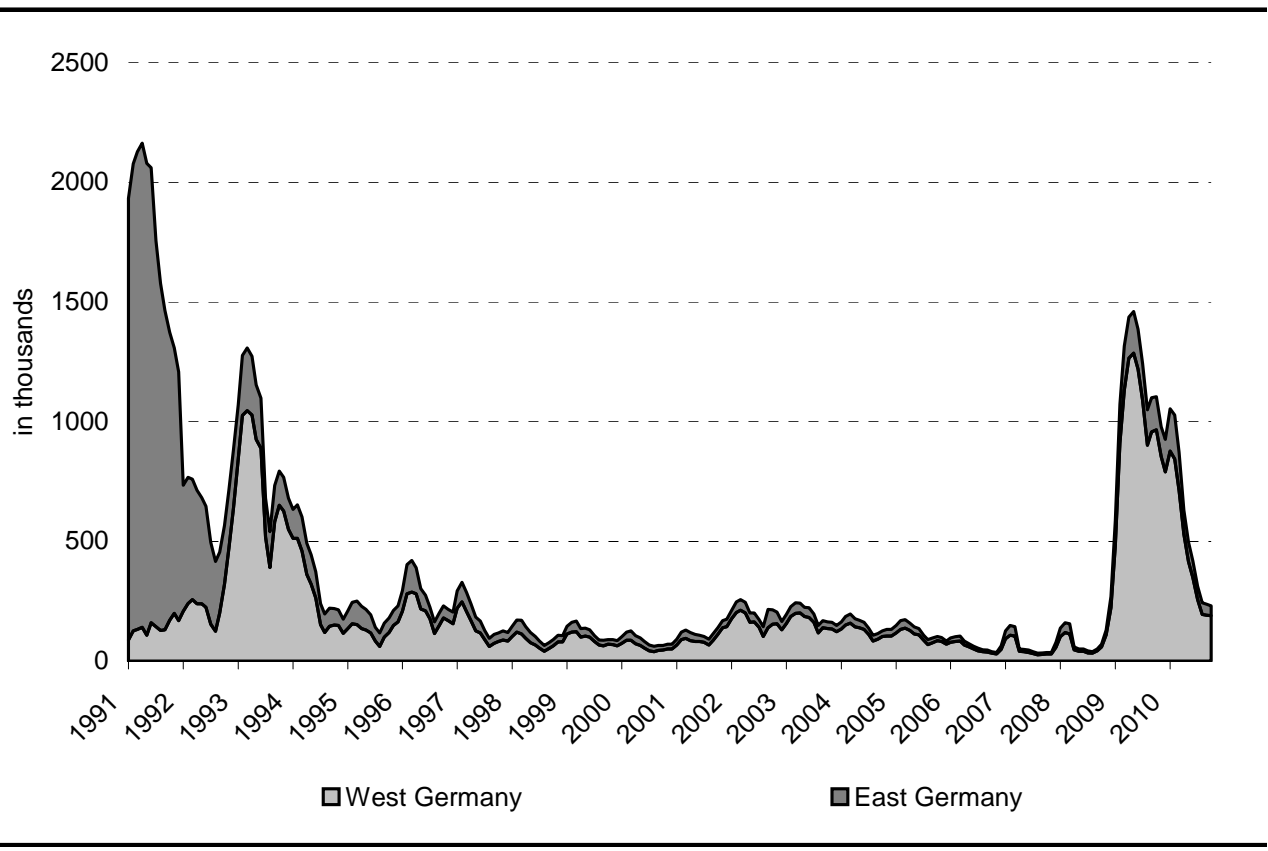

Source: Federal Employment Agency. 
Figure 2

Number of firms with short-time work and short-time workers per firm

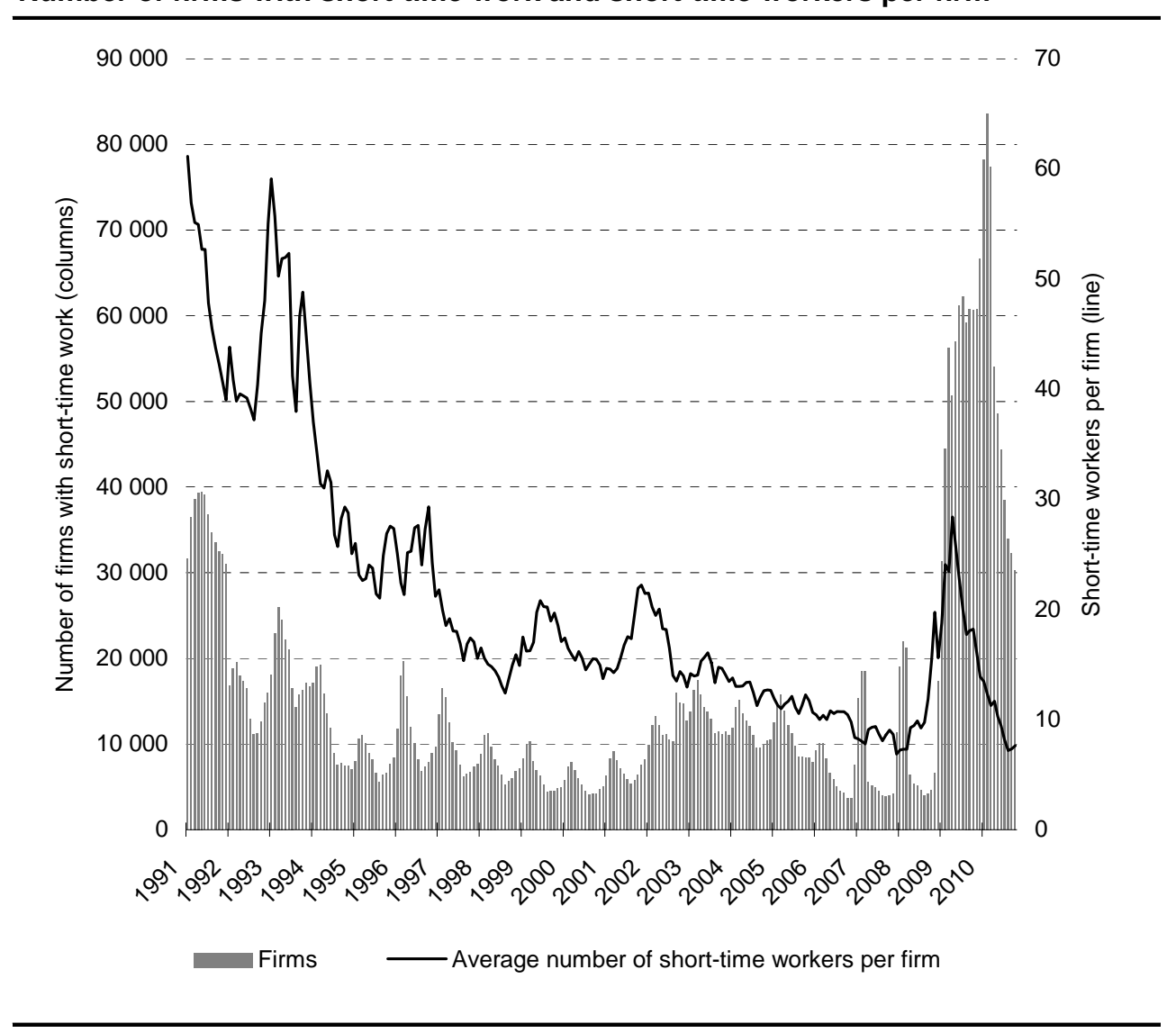

Sources: Federal Employment Agency, own calculations. 
Figure 3

\section{Short-time workers ${ }^{1}$ by sector}

1600000

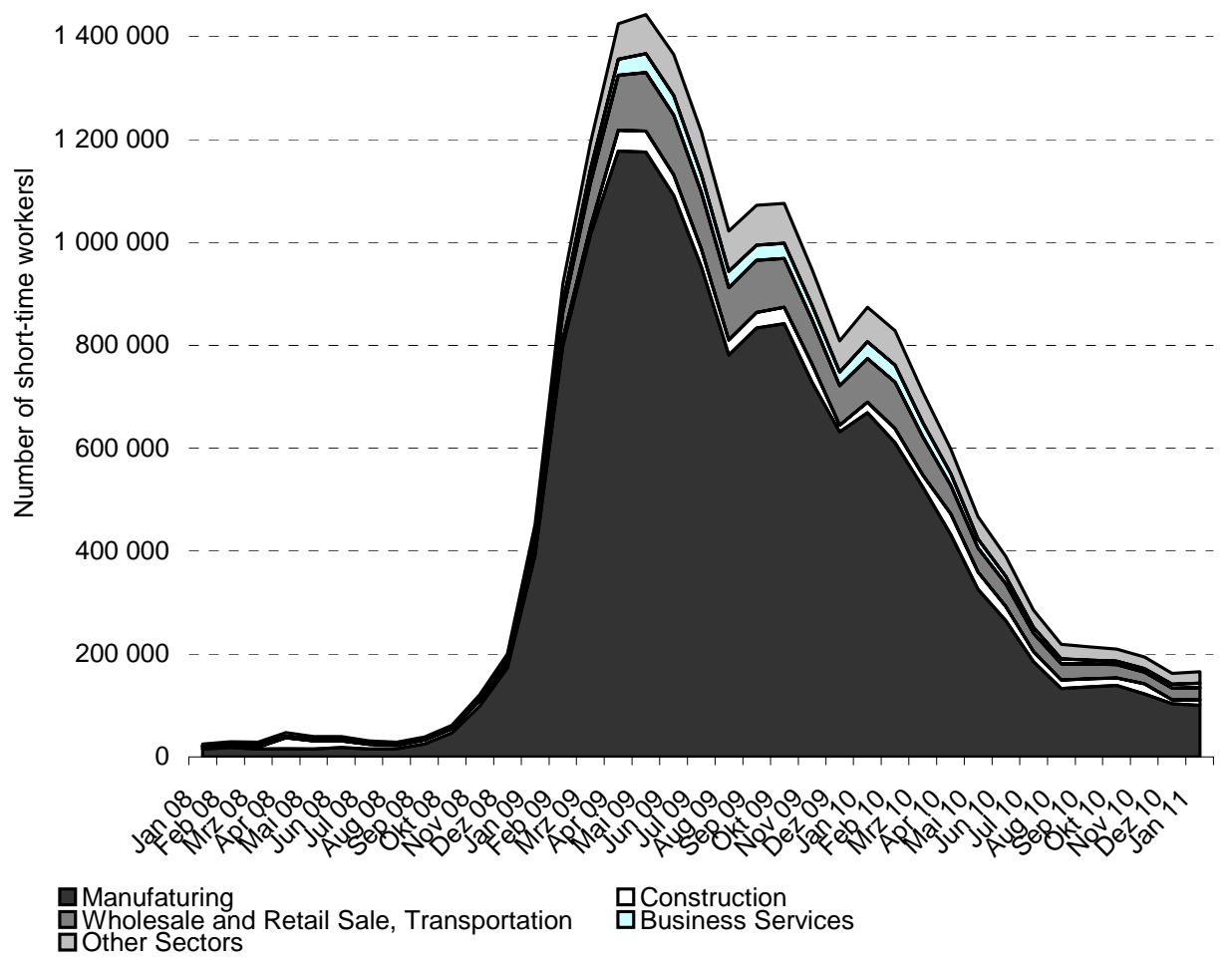

1 Short-time work due to a temporary, cyclical drop in demand.

Sources: Federal Employment Agency, own calculations. 
Figure 4

Short-time work ${ }^{1}$, employment ${ }^{2}$ and unemployment ${ }^{2}$ (since October 2008)

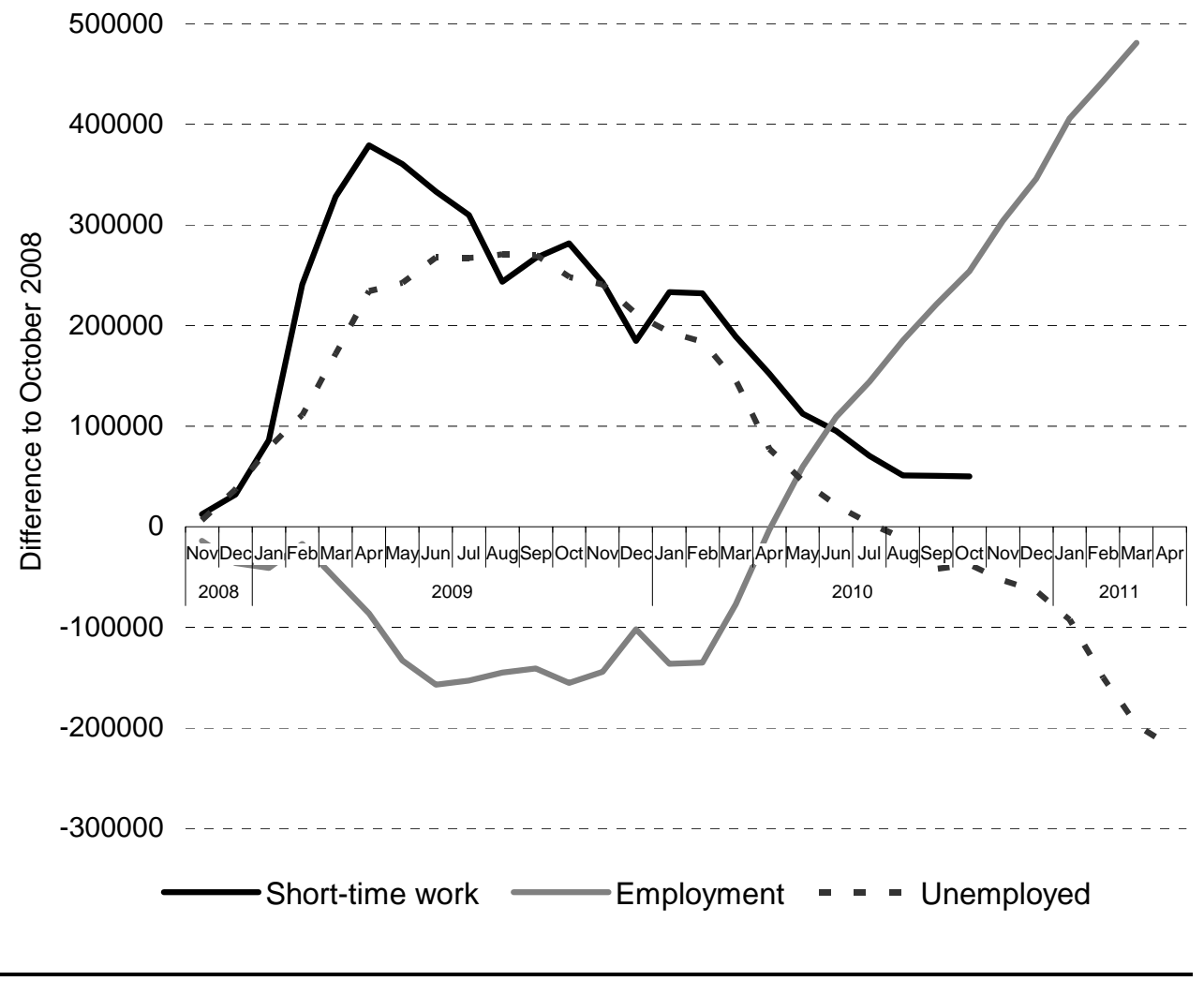

1 Short-time work due to a temporary, cyclical drop in demand, full-time equivalents.

2 Seasonally adjusted.

Sources: Federal Employment Agency, own calculations. 
Figure 5

Number of people firms had planned to assign to short-time work ${ }^{1}$ by sector

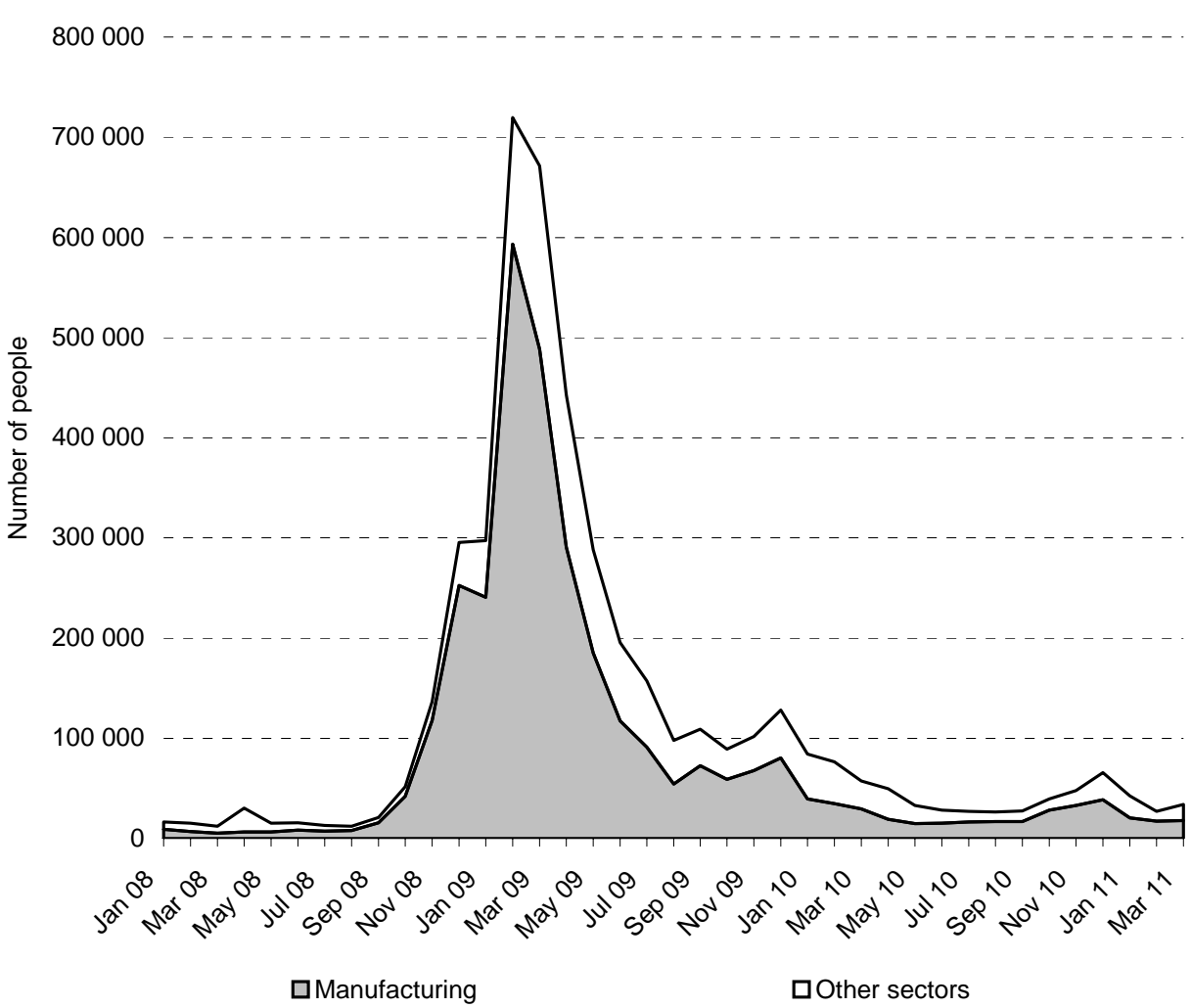

1 Short-time work due to a temporary, cyclical drop in demand.

Sources: Federal Employment Agency, own calculations. 
Figure 6

Number of firms with short-time work and short-time workers ${ }^{1}$ per firm

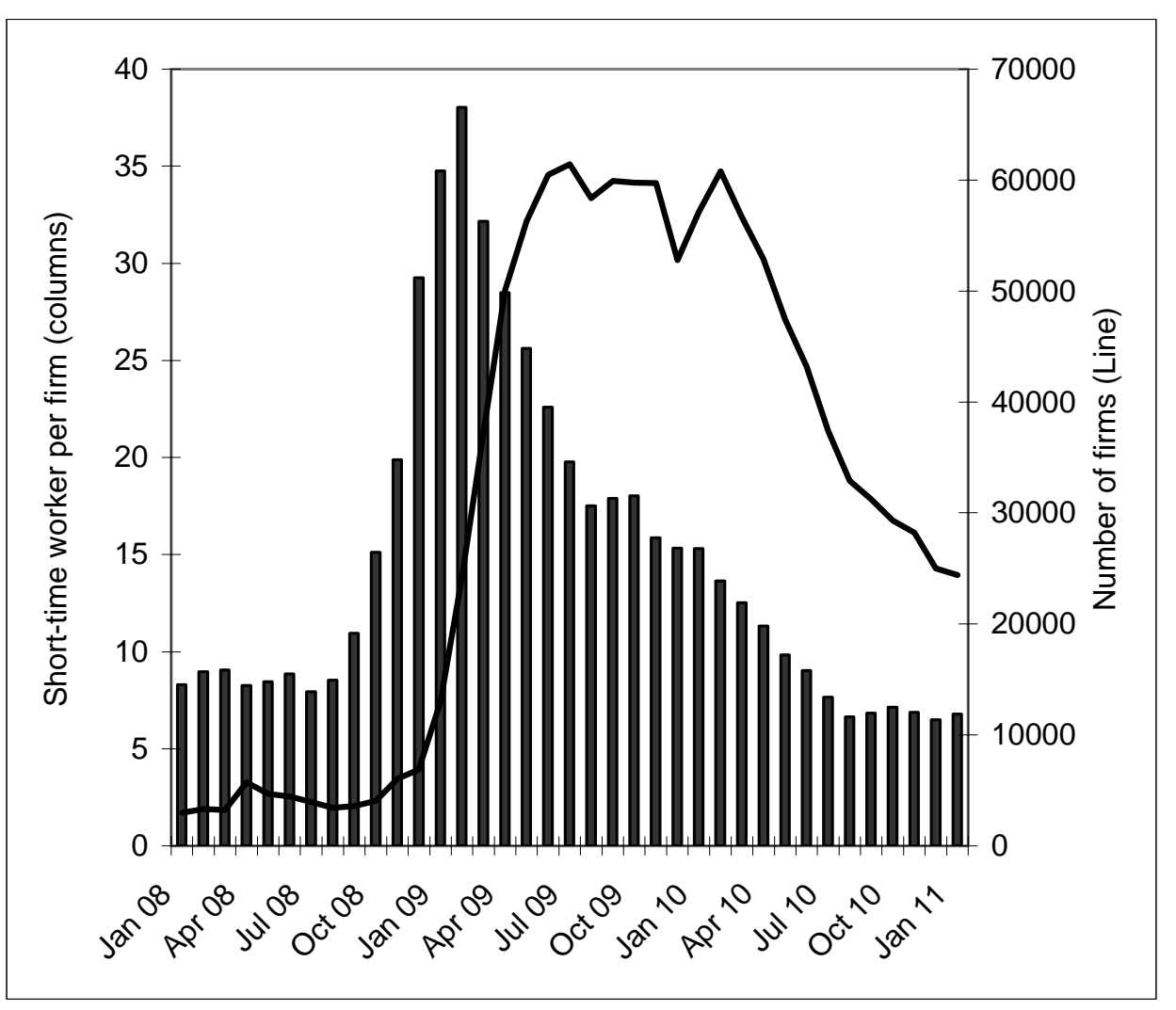

1 Short-time work due to a temporary, cyclical drop in demand.

Sources: Federal Employment Agency, own calculations. 
Figure 7:

Developement of employment and short-time work $^{1}$ in the manufacturing sector

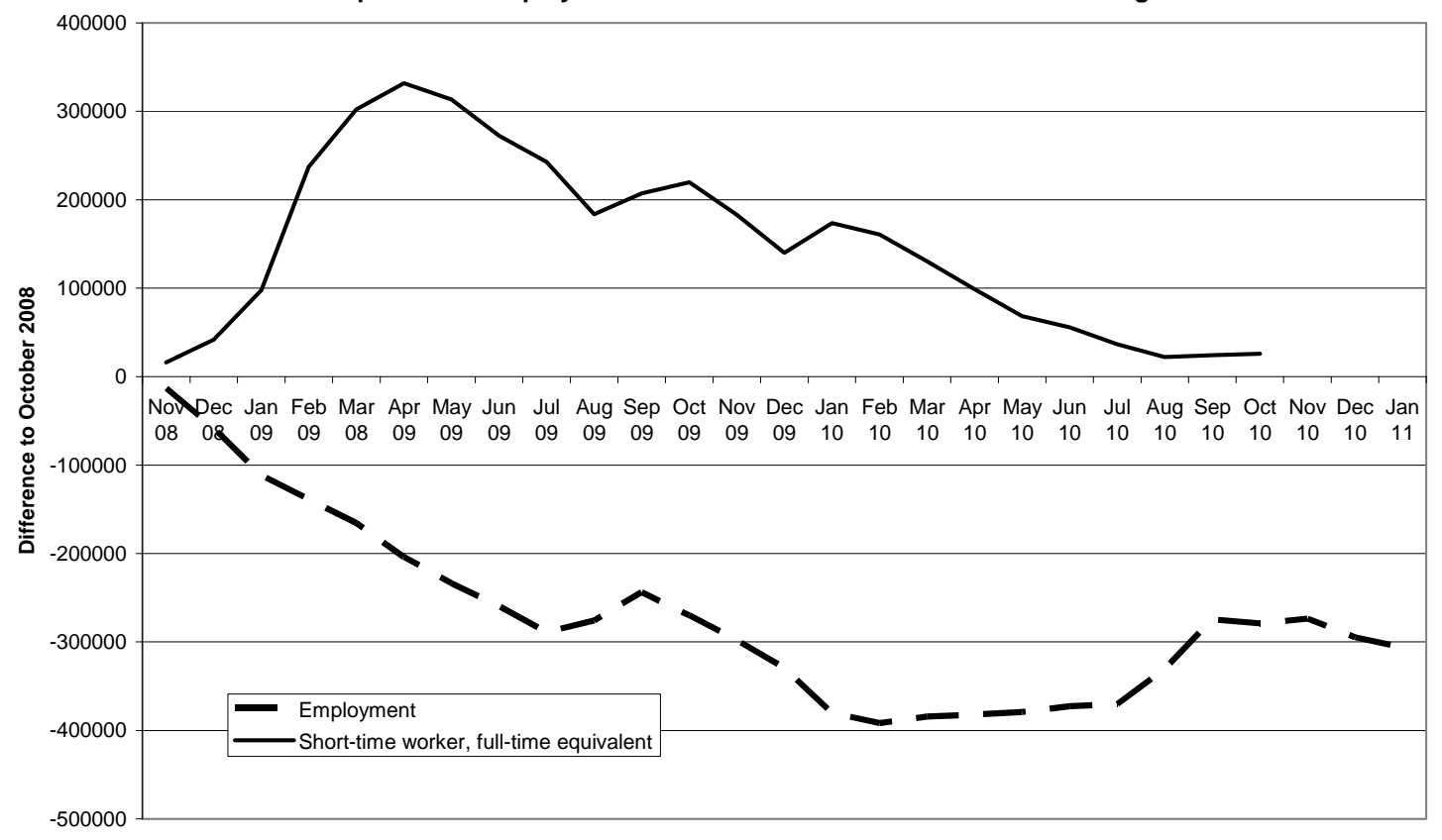

1 Short-time work due to a temporary drop in demand (type 1), full-time equivalents. Sources: Federal Employment Agency, own calculations. 
Figure 8

Short-time workers ${ }^{1}$ by reduction in working hours

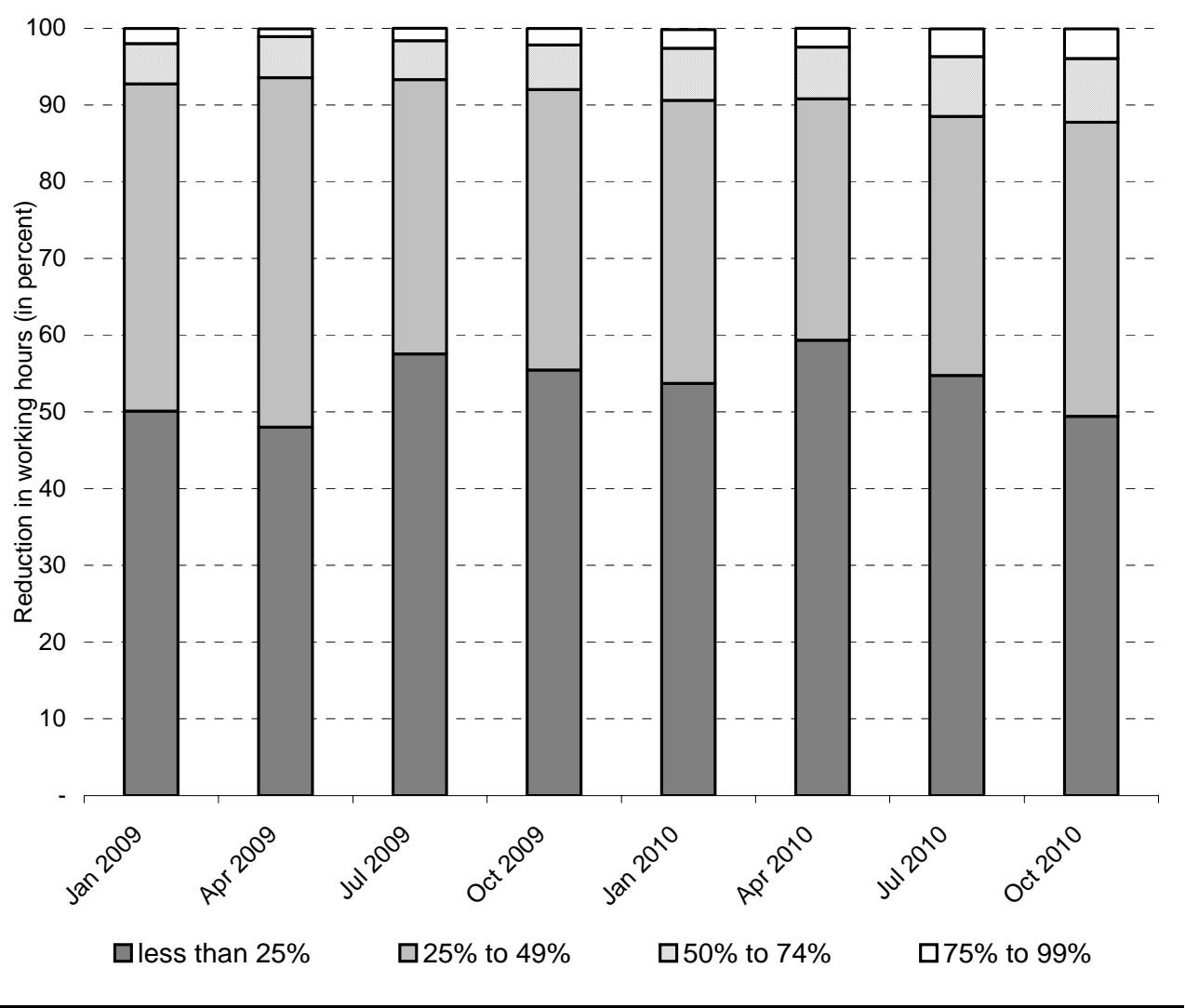

1 Short-time work due to a temporary,cyclical drop in demand.

Sources: Federal Employment Agency, own calculations. 
Figure 9

Number of short-time workers ${ }^{1}$ by duration of short-time work

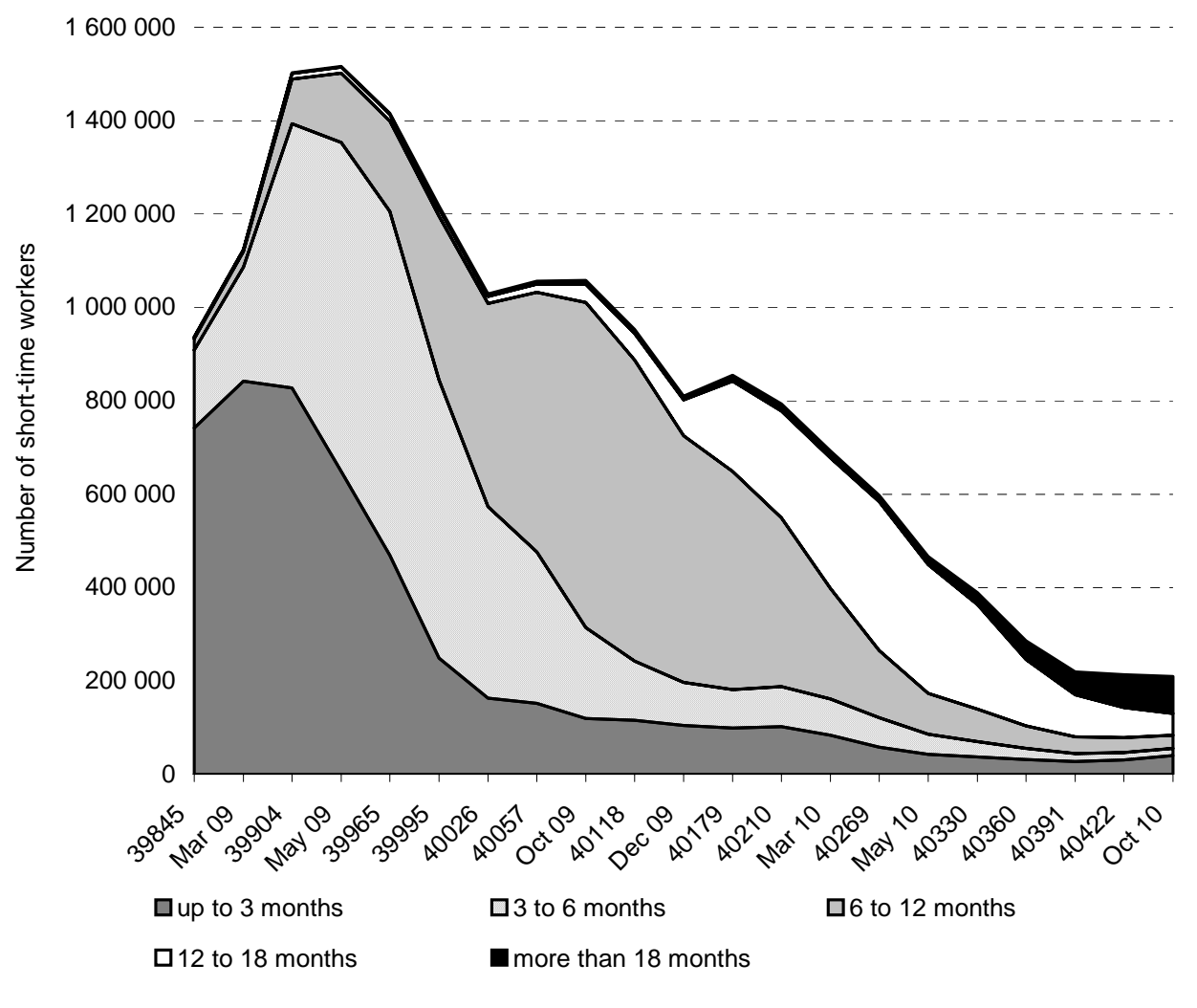

1 Short-time work due to a temporary, cyclical drop in demand.

Sources: Federal Employment Agency, own calculations. 